\title{
Faktor-faktor yang mempengaruhi pendapatan rumah tangga miskin di Kota Jambi
}

\author{
Eriyadi*; Yulmardi; Heriberta
}

\author{
Prodi Magister Ilmu Ekonomi, Program Pascasarjana, Universitas Jambi \\ *E-mail korespondensi:eriyadi_81@Yahoo.co.id
}

\begin{abstract}
Jambi City has several impoverished residents, which is counted 16.632 with the family head. 1) The purpose of this study is to analyze the characteristics of social and economic income of poor household heads in Jambi city 2) Analyzing the influence of education level, type of work, and the number of dependents significantly partially affect the income of poor household heads in Jambi City. With data primary and analyze descriptive and double regression. The results of this study are the level of education, type of work, and the number of simultaneously significant effects on the income of poor heads of households. The level of education, the type of work, and the number of dependents partially have a positive and significant impact on the income of poor household heads. The most dominant independent variables affecting the income of poor household heads in Jambi City are the dependent variable variables.
\end{abstract}

\section{Keyword: Poor households income}

\begin{abstract}
Abstrak
Jumlah rumah tangga miskin di Kota Jambi sebanyak 16.632 kepala rumah tangga. Banyak faktor yang mempengaruhi pendapatan rumah tangga miskin di Kota Jambi.. Penelitian ini bertujuan 1) Untuk menganalisis karakteristik sosial dan ekonomi kepala rumah tanggamiskin di Kota Jambi. 2) Untuk menganalisis pengaruh pendidikan, jumlah tanggungan keluarga, jam kerja dan biaya hidup terhadap pendapatan kepala rumah tangga penduduk miskin di Kota Jambi. Data yang digunakan dalam penelitian ini adalah data primer yang diperoleh melalui kuisioner, sementarametode analisis yang digunakan dalam penelitian ini adalah analisi deskritif dan statistik regresi berganda dengan menggunakan data primer.Hasil penelitian menunjukkan bahwa setiap terjadi peningkatan jam kerja sebesar 1 jam maka akan memberikan pengaruh terhadap peningkatan pendapatan kepala rumah tangga miskin di Kota Jambi sebesar 0,032 \%. Disisi lain peningkatan biaya hidup keluarga miskin akan mendorong terjadinya peningkatan pendapatan keluarga miskin sebesar 0,237\%. Hal ini memberikan gambaran bahwa penggunaan jam kerja yang secara positif akan mendorong semakin bertambahnya pendapatan keluarga miskin. Nilai $\mathrm{R}^{2}$ sebesar 0,289. Artinya sebesar 28,9 persen variasi pendapatan kepala rumah tangga miskin mampu dijelaskan oleh variabel bebas dalam model, sedangkan sisanya 71,1 persen dijelaskan oleh variabel lain diluar penelitian. Secara bersama-sama dan secara parsial variabel jam kerja dan variabel biaya hidup berpengaruh signifikan terhadap pendapatan kepala rumah tangga miskin di Kota Jambi.
\end{abstract}

Kata kunci: Pendapatan rumah tangga miskin

PENDAHULUAN

selama tahun 2015-2019 jumlah kepala rumah tangga miskin yang ada di 11 kecamatan Kota Jambi terus mengalami penurunan dari waktu ke waktu, yaitu dari 
17.880 rumah tangga miskin tahun 2015 menjadi 16.632 rumah tangga miskin Pada tahun 2019. Meskipun mengalami penurunan sebesar 1.248 keluarga miskin selama lima tahun terakhir, namun pada kenyataannya angka tersebut cukup besar karena jika dibandingkan dengan total jumlah keluarga di Kota Jambi tahun 2019 sebanyak 141.887 kepala rumah tangga atau keluarga miskin mempunyai proporsi sebesar 11,72 persen terhadap total keluarga yang ada di Kota Jambi. Angka ini masih di atas satu digit dan cukup tinggi, sebab tingginya angka kemiskinan akan menjadi beban dalam pembangunan Kota Jambi, terutama bila dikaitkan dengan upaya pemerintah Kota Jambi yang ingin meningkatkan kualitas hidup masyarakat, layak huni dan memiliki kenyamanan bagi warganya.

Jumlah keluarga miskin tinggi berada di Kecamatan Jambi Timur, dengan jumlah 3.091 kepala rumah tangga, sementara jumlah keluarga miskin terendah berada di Kecamatan Pelayangan yaitu sebesar 376 rumah tangga. Tingginya proporsi keluarga miskin di Kota Jambi salah satunya disebabkan oleh faktor pendapatan keluarga rumah tangga miskin yang rendah. Penelitian ini dilakukan di Kecamatan Jambi Timur, Kecamatan Selatan dan Kecamatan Kota Baru. Pemilihan objek penelitian ditentukan berdasarkan pertimbangan bahwa tiga kecamatan ini adalah kecamatan yang memiliki jumlah rumah tangga miskin di Kota Jambi, sehingga diharapkan dapat memberikan gambaran atau fenomena yang menyebabkan rendahnya pendapatan rumah tangga miskin di Kota Jambi.

Pendapatan merupakan salah satu indikator tingkat kesejahteraan masyarakat, semakin membaik pendapatan masyarakat maka akan semakin besar pula tingkat kesejahteraan masyarakat. Untuk itu pendapatan keluarga miskin dapat menjadi kunci dalam memajukan kesejahteraan masyarakat yang merata dan lebih berkeadilan. Bila pendapatan keluarga miskin bertambah, secara otomatis maka perekonomian suatu daerah pun akan mengalami perubahan yang positif. Berdasarkan observasi awal kepada salah satu penduduk miskin di Kecamatan Jambi Timur bahwa pendapatannya tidak sampai Rp. 2,5 juta perbulannya, sedangkan dengan pendapatan tersebut untuk hidup dengan memiliki jumlah tanggungan yang banyak dan biaya hidup seperti barangbarang kebutuhan pokok yang terus meningkat maka pendapatan tersebut bisa dikatakan tidak cukup untuk memenuhi kebutuhan hidup. Padahal kebutuhan harus terpenuhi apalagi yang menyangkut kebutuhan dasar bagi keluarga seperti makanan, pakaian, dan perumahan.

Berbicara masalah pendapatan maka banyak faktor yang dapat mempengaruhi pendapatan tersebut. Menurut Rahardja dan Manurung (2008) semakin tinggi pendidikan seseorang pengeluaran konsumsinya juga akan semakin tinggi, sehingga mempengaruhi pola konsumsi dan hubungannya positif. Pada saat seseorang atau keluarga memiliki pendidikan yang tinggi, kebutuhan hidupnya semakin banyak. Artinya, penduduk yang mempunyai pendidikan lebih tinggi akan mampu meningkatkan pendapatannya. Berdasarkan observasi awal kepada salah satu penduduk miskin di Kecamatan Jambi Timur memiliki pendidikan yang rendah, rata-rata kepala rumah tangga penduduk miskin paling tinggi hanya berpendidikan SMA atau menghabiskan 12 tahun untuk pendidikan formal. Masalah rendahnya pendidikan keluarga miskin ini pada akhirnya akan menghambat kreativitas dan kemampuan kepala rumah tangga dalam mengelola potensi ekonomi yang dimilikinya

Jumlah tanggungan keluarga mempunyai hubungan yang erat dengan kemiskinan. Besarnya jumlah tanggungan keluarga akan berpengaruh terhadap pendapatan karena dengan semakin banyaknya jumlah tanggungan keluarga atau jumlah anggota keluarga yang ikut makan maka secara tidak langsung akan memaksa tenaga 
kerja tersebut untuk mencari tambahan pendapatan (Simanjuntak, 2001). Berdasarkan observasi awal kepada salah satu penduduk miskin di Kecamatan Kota Baru bahwa jumlah tanggungannya sejumlah 4 orang, dengan pendapatan di bawah Rp. 2 Juta, dengan pendapatan sebesar ini sangat berat bagi kepala keluarga untuk memenuhi sebagian besar kebutuhan hidupnya, termasuk dalam membiayai kegiatan pendidikan, kesehatan dan kebutuhan lainnya.

Salah satu faktor penting dalam menghasilkan pendapatan adalah menentukan jam kerja. Jam kerja adalah banyaknya lama waktu kerja dalam sehari (Asmie, 2008). Satuan variabel jam kerja adalah jam per hari. Jika ingin memperoleh pendapatan yang tinggi maka diperlukan jam kerja yang tinggi pula. Semakin lama jam kerja atau operasional seseorang bekerja maka akan semakin tinggi pula kesempatan untuk memperoleh pendapatan yang tinggi. Berdasarkan observasi awal kepada salah satu penduduk miskin di Kecamatan Jambi Selatan bahwa jam kerjanya lebih dari 8 jam.

Menurut Rahardja dan Manurung (2008) bahwa pendapatan rumah tangga bergantung terhadap biaya hidup. Biasanya semakin besar biaya hidup maka semakin besar pendapatan hal ini dikarenakan biaya hidup dengan beberapa jumlah tanggungan yang harus ditanggung akan menjadi tuntutan kepala rumah tangga untuk meningkatkan pendapatannya. Sehingga biasanya penduduk miskin yang berada dalam kondisi seperti ini sangat sulit untuk keluar dari garis kemiskinan. Tentu saja akan terjadi perbedaan pendapatan antar keluarga miskin, khususnya di Kota Jambi yang disebabkan oleh faktor-faktor yang telah diuraikan sebelumnya. Perbedaan ini secara langsung akan berdampak terhadap variasi naik turunnya pendapatan keluarga miskin yang ada di Kota Jambi.

Berdasarkan uraian-uraian sebagaimana telah disebutkan di atas maka peneliti merasa perlu untuk mengkaji lebih jauh tentang faktor-faktor yang mempengaruhi pendapatan kepala rumah tangga miskin dengan judul "Faktor-faktor yang mempengaruhi pendapatanrumah tangga Miskin di Kota Jambi”.

\section{METODE}

\section{Lokasipenelitian}

Penelitian ini akan dilakukan di Kecamatan Jambi Timur, Jambi Selatan dan kota Baru. Dipihnya lokasi tiga kecamatan ini karena pertimbangan bahwa jumlah penduduk miskin di tiga kecamatan ini adalah jumlah penduduk miskin terbesar yang ada di Kota Jambi.

\section{Jenis data}

Jenis data yang digunakan dalam penelitan ini adalah data primer dan data sekunder. Data primer adalah data yang langsung diperoleh penelitian di lapangan, sementara data sekunder diperoleh dari instansi terkait. Data primer yang digunakan dalam penelitian ini terdiri dari data Karakteristik Sosial ekonomi yang yang meliputi tingkat pendidikan, umur, jumlah tanggungan keluarga, biaya hidup, penggunaan jam kerja dan tingkat pendapatan rumah tangga miskin yang ada di Kota Jambi.Data Sekunder adalah jumlah rumah tangga miskin di Kota Jambi yang diambil dari Dinas Sosial Provinsi Jambi dan Dinas Sosial Kota Jambi

\section{Metode pengumpulan data}

MetodePengumupulandatayangdigunakandalamkajianiniadalahmelalui

wawancara terstruktur dengan responden, yaitu rumah tangga miskin yang ada di Kota Jambi. Wawancara dilakukan dengan menggunakan kuisioner yang telah disusun sebagai petunjuk 


\section{Teknik analisis}

Metode analisis kuantitatif dalam penelitian inimenggunakan analisis regresi linear berganda. Analisis Regresi adalah studi mengenai ketergantungan variabel dependen (terikat) pendapatan rumah tangga miskin dan pendidikan, jumlah tanggungan keluarga, jam kerja dan biaya hidupsebagai variabel independen (variabel bebas).Persamaan Regresi linier berganda dikemukakan oleh Sugiyono (2014) dapat dilihat sebagai berikut :

\section{Uji normalitas}

$$
Y=\alpha+b_{1} X_{1}+b_{2} X_{2}+b_{3} X_{3}+b_{4} X_{4}+\mathrm{e}
$$

Menurut Ghozali (2012) uji normalitas bertujuan apakah dalam model regresi variabel dependen dan variabel independen mempunyai kontribusi atau tidak. Model regresi yang baik adalah data distribusi normal atau mendekati normal.Uji ini menggunakan plot pada grafik, apabila plot berada pada garis diagonal maka data dapat dikatakan berdistribusi normal.

\section{Uji multikolinieritas}

Menurut Gani dkk (2015) uji multikolinearitas bertujuan untuk menguji adanya hubungan linear yang sempurna atau pasti di antara beberapa atau semua variabel yang menjelaskan dari model regresi. Ada atau tidaknya multikolinearitas dapat diketahui atau dilihat dari koefisien korelasi masing-masing variabel bebas.

Gejala adanya multikolinearitas dapat di deteksi dengan menggunakan beberapa metode antara lain (Gujarati, 2005) Ketika $\mathrm{R}^{2}$ tinggi dan ketika korelasi derajat nol juga tinggi, tetapi tak satupun atau sangat sedikit koefisien regresi parsial yang secara individual penting secara statistik atas dasar pengujian t. Jika $\mathrm{R}^{2}$ tinggi, ini akan berarti bahwa uji $\mathrm{F}$ akan sangat penting atau signifikan, meskipun nilai uji $\mathrm{t}$ sebaliknya. Dengan demikian perlu diingat bahwa gejala multikolinearitas hanya ada pada model dengan lebih dari satu variabel bebas (multi regresi).

Kuat tidaknya korelasi antara variabel bebas dapat dilihat dari matriks korelasi diantara variabel-variabel yang ada dalam model Makridakis, 1994. Adapun cara mengatasinya adalah dengan mengeluarkan salah satu variabel bebas dalam model atau menambah jumlah data dengan pengamatan baru Pengujian multikolinearitas dilihat dari besaran VIF (Variance Inflation Factor) dan tolerance.

\section{Uji autokorelasi}

Adalah suatu keadaan dimana variabel gangguan pada periode tertentu berkorelasi dengan variabel gangguan pada periode lainnya, dengan kata lain variabel gangguan tidak random atau korelasi diantara variabel gangguan yang berurutan dari data time series. Dalam konteks penelitian masalah auto korelasi mungkin timbul akibat antara lain. 1) Model yang bersifat auto regresif (adanya lag waktu 2) Kesalahan dalam menentukan model 3) Tidak memasukkan variabel yang penting (Gudjarati, 2005)

Menurut Gudjarati (2005) akibat auto korelasi maka parameter yang diestimasi menjadi bias dan variannya tidak minimum sehingga tidak efisien. Untuk mendeteksi adanya gejala autokorelasi di dalam model maka digunakan Uji Durbin-Watson Statistik. Hasil Uji Durbin -Watson dibandingkan dengan Durbin Watson tabel, bila pengujian terletak didaerah inconculsive (tidak dapat disimpulkan), maka dianggap ada autokorelasi

Menurut Ghozali (2012) uji autokorelasi bertujuan menguji apakah dalam model regresi ada kolerasi antara kesalahan pengganggu pada periode-t dengan 
kesalahan pengganggu pada padaperiode t-1 (sebelumnya). Pengujian autokolerasi dilakukan dengan uji durbin watson dengan membandingkan nilai durbin watson hitung

\section{Heteroskedastisitas}

Menurut Gani dkk (2015)uji heteroskedastisitas adalah kondisi dimana varian dari nilai sisa adalah tidak sama (unequal) antara satu observer (pengamatan) dengan observer lainnya. Jika varian dan nilai sisa sama (equal) antara satu observer dengan observer lainnya, maka kondisi ini disebut dengan kondisi homoskedastisitas.

\section{Pengujian hipotesis}

\section{Uji simultan}

Menurut Sutrisno (2006) uji Statistik F pada dasarnya digunakan untuk menguji besarnya pengaruh dari seluruh variabel independen secara bersama-sama (simultan) terhadap variabel dependen.

\section{Uji parsial}

Menurut Ghozali (2012) Uji beda t-test digunakan untuk menguji seberapa jauh pengaruh variabel independen yang digunakan dalam penelitian ini secara individual dalam menerangkan variabel dependen secara parsial.

\section{Koefisien determinasi $\left(\boldsymbol{R}^{2}\right)$}

Menurut Ghozali (2012) koefisien determinasi $\left(\mathrm{R}^{2}\right)$ merupakan alat untuk mengukur seberapa jauh kemampuan model dalam menerangkan variasi variabel dependen. Nilai koefisien determinasi adalah antara nol atau satu. Nilai $\mathrm{R}^{2}$ yang kecil berarti kemampuan variabel-variabel independen dalam menjelaskan variasi variabel dependen amat terbatas.

\section{HASIL DAN PEMBAHASAN}

\section{Karakteristik pendidikan}

gambaran keadaan tingkat pendidikan responden berdasarkan pendidikan formal yang pernah dijalani atau ditamatkan. Proporsi responden yang menamatkan pendidikan atau tidak menamatkan pada level Sekolah Dasar (SD) adalah sebanyak 23 responden atau sebesar $23,47 \%$ dari jumlah total reponden, sementara yang menamatkan atau tidak menamatkan Sekolah Menengah Pertama (SMP) adalah sebanyak 36 responden atau sebesar $36,73 \%$ dan responden yang menamatkan atau tidak menamatkan pada tingkat Sekolah Menengah Atas (SMA) adalah sebanyak 39 responden atau sebesar 39,80\% dari total jumlah responden yang ada. Proporsi kepala rumah tangga miskin yang menamatkan atau tidak menamatkan pendidikan tingkat SMA ternyata adalah proporsi yang terbesar, hal ini memberikan gambaran bahwa sebagian besar kepala rumah tangga miskin di Kota Jambi sudah memiliki tingkat pendidikan yang cukup matang, meskipun belum pada tingkat yang memiliki kemandirian dan keahlian.

\section{Karakteristik jumlah tanggungan responden}

jumlah responden kepala rumah tangga miskin di Kota Jambi berdasarkan jumlah tanggungan keluarga sebagian besar berada pada interval antara $2-4$ orang, yaitu sebanyak 76 responden atau sebesar $77,55 \%$, sementara yang memiliki tanggungan sebanyak $7-8$ orang adalah sebanyak 2 responden atau sebesar 2,04\%. 
Secara rata-rata jumlah tanggungan responden adalah sebanyak 4 orang. Dengan demikian rata-rata responden memiliki jumlah anak sebanyak 3 orang dengan 1 orang istri. Jumlah ini masih melebih kriteria Keluarga Berencana dan mensyaratkan dua orang anak cukup.

\section{Karakteristik jam kerja responden}

Jumlah kepala rumah tangga miskin berdasarkan jam kerja menunjukkan sebanyak 16 responden atau sebesar 16,33\% memiliki jam kerja sebanyak 7-8 jam per hari, kemudian sebanyak 60 responden atau sebesar 61,22\% memiliki jam kerja antara 9-10 jam perhari dan yang memiliki jam kerja sebanyak 11-12 jam perhari. Secara keseluruhan proporsi penggunaan jam kerja terbesar berada pada kelompok 9-10 jam perhari. Jumlah ini tentu saja menunjukkan tingginya curahan keluarga miskin dalam bekerja namun tentu saja pendapatannya tidak sebanding dengan waktu yang dikeluarkan. Hal ini disebabkan pada umumnya responden bekerja di sektor informal yang memiliki efisiensi waktu yang lebih rendah dibandingkan dengan bekerja di sektor formal. Secara rata-rata jam kerja yang digunakan oleh responden adalah sebanyak 10 jam perhari. Bila diasumsikan responden dalam waktu satu minggu memiliki waktu istirahat sehari, maka jam kerja responden adalah sebanyak 60 jam perminggu.

\section{Karakteristik biaya hidup responden}

Jumlah kepala rumah tangga miskin berdasarkan biaya hidupyaitu kepala rumah tangga yang mengeluarkan biaya hidup untuk kebutuhan keluarga sebesar Rp. 1.100.000 - 2.000.000sebanyak 62orang atau sebesar 63,27\% dari total jumlah responden yang ada, sementara responden yang mengeluarkan biaya hidupuntuk kebutuhan keluarga miskin sebesar Rp. 2.100.000 - 3.000.000 perbulan adalah sebanyak 33 orang atau sebesar 33,67 \% dari total responden dan yang mengeluarkan biaya hidup untuk kebutuhan keluarga sebesar Rp. 3.100.000 - 4.000.000hanya sebanyak 3 orang.

Berdasarkan hasil tersebut, dapat dikatakan bahwa rata-rata kepala rumah tangga mengeluarkan biaya hidup untuk kebutuhan anggota keluarga sebanyak Rp. 2.061.000 perbulan, bila diasumsikan jumlah tanggungan keluarga sebanyak 4 orang maka dengan menghitung jumlah seluruh anggota keluarga rumah tangga miskin termasuk kepala rumah tangga adalah sebanyak 5 orang maka pengeluaran perkapita rumah tangga miskin di Kota Jambi responden adalah sebesar Rp. 414.000 perbulan. Jumlah ini masih sangat jauh dari pengeluaran yang layak yang disyaratkan sebagai penentuan batas garis kemiskinan di Kota Jambi sebesar Rp. 512.000 perkapita perbulan.

\section{Karakteristik pendapatan responden}

Penggolongan rumah tangga miskin biasanya mengacu kepada poverty gap atau mengacu kepada pendapatan rumah tangga. Pendapatan kepala keluarga rumah tangga miskin biasanya jauh dari kemampuan memenuhi kebutuhan minimal keluarga.proporsi terbesar pendapatan responden berada pada kelas interval Rp. 1.600.000 - 2.000.000, yaitu sebanyak 47 responden atau sebesar 47,96\%. Sementara yang berpendapatan Rp. $2.600 .000-3.000 .000$ perbulan adalah sebanyak 4 responden atau sebesar4,05\%. Dengan rata-rata pendapatan sebesar Rp. 1.800 .000 perbulan maka dalam satu keluarga miskin pendapatan perkapita adalah sebesar Rp. 375.000 perkapita perbulan. Angka ini masih jauh dari batas garis kemiskinan untuk Kota Jambi sebesar Rp. 512.000. Selilih antara rata-rata pendapatan perkapita responden dengan batas garis kemiskinan ini menjadi defisit anggaran rumah tangga miskin responden yang harus dipenuhi keluarga agar kebutuhan pokok rumah tangga miskin responden dapat terpenuhi dengan layak. 


\section{Kaitan pendidikan responden dengan tingkat pendapatan}

Pendidikan secara tidak langsung terkait dan berpengaruh terhadap pendapatan seseorang. Secara teoritis semakin tinggi tingkat pendidikan formal yang ditamatkan oleh seseorang maka akan semakin maju dan kreatif dalam mencari sumber-sumber pendapatan, meskipun tidak selalu demikian adanya, kadang-kadang mereka yang tidak berpendidikan tinggi memiliki kematangan berfikir karena memiliki pengalaman hidup yang lebih dibandingkan mereka yang memiliki pendidikan formal yang tinggi. Pendidikan yang lebih tinggi juga memungkinkan orang untuk lebih produktif karena akan lebih mudah dilatih untuk memperoleh skill dalam melakukan pekerjaannya.

Pendapatan responden menurut tingkat pendapatan menunjukkan bahwa pada pendapatan antara Rp. 1.100.000 - 1.500.000proporsi mereka yang berada pada kelompok pendidikan yang menamatkan atau belum menamatkan SD merupakan proposi terbesar yang sekaligus memberikan gambaran bahwa pendidikan yang lebih rendah pada keluarga miskin memiliki pendapatan yang lebih rendah bila dibandingkan dengan mereka yang berpendidikan lebih bak. Hal yang sama terjadi pada kelompok pendapatan antara Rp. 1.600.000 - 2.000.000 yang memperlihatkan bahwa proporsi pendidikan yang lebih rendah ternyata memiliki pendapatan yang lebih rendah dari rumah tangga miskin yang memiliki pendidikan yang jauh lebih rendah, begitu juga dengan pendapatan pada interval Rp 2.100.000 - 2.500.000 yang memperlihatkan pendidikan yang lebih baik memiliki pendapatan yang lebih baik dibandingkan dengan mereka yang berpendidikan yang kebih rendah.

Secara keseluruhan dengan tingkat pendidikan rata-rata responden sebesar 9 tahun atau menamatkan pendidikan SMP, pendapatan responden adalah sebesar Rp. 1.800 .000 perbulan. Gambaran perbandingan antara tingkat pendidikan dan pendapatan ini mencerminkan bahwa tingkat pendidikan pada keluarga miskin yang lebih rndah akan mendapatkan yang lebih baik rendah diantara rumah tangga itu sendiri. Hal in imenunjukkan bahwa pendidikan secara kualitatif akan berpengaruh terhadap pendapatan keluarga miskin yang ada di Kota Jambi.

\section{Kaitan jumlah tanggungan keluarga responden dengan tingkat pendapatan}

Ketidakmampuan dalam menyediakan kebutuhan anggota keluarga secara layak dan manusiawi menyebabkan anggota keluarga tidak mampu tumbuh dan berkembang secara baik, meski demikian tidak selalu adanya.Adapun gambaran pendapatan rumah tangga miskin dengan jumlah tanggungan keluarga tergambar pada tabel berikut

Tabel 1. Pendapatan responden berdasarkan jumlah tanggungan keluarga

\begin{tabular}{ccccccc}
\hline \multirow{2}{*}{ No. } & Pendapatan (Rupiah) & \multicolumn{4}{c}{ Tanggungan Keluarga (Jiwa) } & \multirow{2}{*}{ Frekuensi } \\
\cline { 3 - 5 } & $\mathbf{2 - 4}$ & $\mathbf{5 - 6}$ & $\mathbf{7 - 8}$ & \\
\hline 1 & $1.100 .000-1.500 .000$ & 21 & 5 & 0 & 26 \\
2 & $1.600 .000-2.000 .000$ & 36 & 10 & 1 & 47 \\
3 & $2.100 .000-2.500 .000$ & 17 & 3 & 1 & 21 \\
4 & $2.600 .000-3.000 .000$ & 2 & 2 & 0 & 4 \\
\hline & Jumlah & $\mathbf{7 6}$ & $\mathbf{2 0}$ & $\mathbf{2}$ & $\mathbf{9 8}$ \\
\hline
\end{tabular}

Sumber : Data diolah, 2020

Berdasarkan Tabel 1 terlihat bahwa pada kelas interval Rp. $1.100 .000-$ 1.500.000 proporsi responden terbesar adalah mereka yang memiliki memiliki tanggungan keluarga antara 2-4 orang. Pada interval ini memperlihatkan bahwa semakin kecil jumlah tanggungan keluarga miskin ternyata memiliki pendapatan yang lebih rendah pula. Begitu juga dengan kelas interval Rp.1.600.000 - 2.000.000 ternyata 
memiliki jumlah tanggungan keluarga yang lebih kecil dibandingkan dengan mereka yang memiliki jumlah tanggungan keluarga yang lebih besar.

\section{Pengaruh pendidikan, jumlah tanggungan keluarga, jam kerja dan biaya hidup terhadap pendapatan kepala rumah tangga penduduk miskin di Kota Jambi Persamaan regresi}

Estimasi koefisien regresi adalah estimasi terhadap seluruh variabel bebas yang meliputi (Pendidikan, Jumlah Tanggungan Keluarga, Jam Kerja dan Biaya Hidup) terhadap variabel terikat (Pendapatan Kepala Rumah Tangga Miskin). Adapun persamaan regresinya adalah sebagai berikut:

Tabel 2. Angka-angka analisis regresi

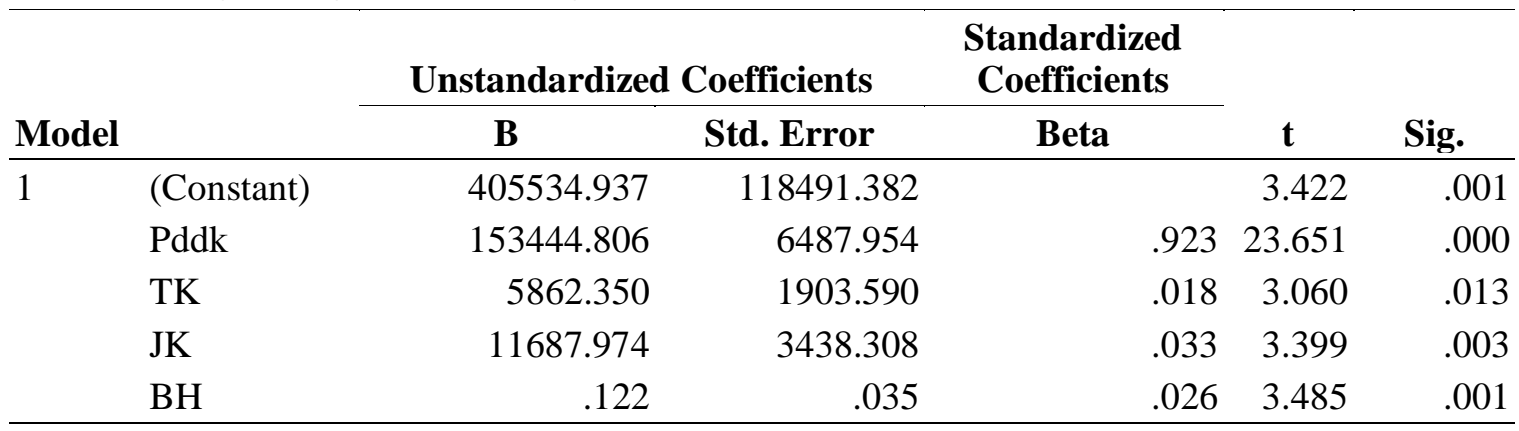

Sumber : Data diolah, 2020

Berdasarkan tabel 2 maka dapat disusun model persamaan regresi linear berganda sebagai berikut

$$
\begin{array}{r}
\mathrm{PRT}=405.534,93+153.000,80 \mathrm{Pdkk}+5.862,35 \mathrm{JT}+11.687,97 \mathrm{JK}+0,122 \mathrm{BH} \\
\mathrm{t}_{\text {hit }}(23,651) \\
\mathrm{R}^{2}=0,899 \quad \mathrm{~F}_{\text {hit }}=207,893 \quad \mathrm{DW}_{\text {hit }}=1,947
\end{array}
$$

Berdasarkan model persamaan regresi berganda di atas terlihat bahwa pengaruh tingkat pendidikan adalah sebesar Rp. 153.000, 80. Artinya setiap terjadi peningkatan pendidikan kepala rumah tangga responden sebesar 1 tahun maka pendapatan responden kepala rumah tangga miskin di Kota Jambi akan meningkat sebesar RP. 153.000, sementara setiap terjadi peningkatan jumlah anggota keluarga sebesar 1 jiwa maka pendapatan keluarga akan mengalami peningkatan sebesar Rp. 5.862, sementara penambahan 1 jam kerja akan mendorong peningkatan pendapatan keluarga miskin sebesar Rp. 11.687 dan setiap penambahan biaya hidup sebesar Rp.1 maka pendapatan akan mengalami peningkatan sebesar Rp. 0,122. Hasil penelitian ini menunjukkan bahwa pengaruh tingkat pendidikan, tanggungan keluarga, jam kerja dan biaya hidup terhadap pendapatan keluarga miskin adalah positif. Hasil penelitian ini memperkuat penelitian-penelitian yang telah dilakukan dimana variabel tersebut memperlihatkan pengaruh yang positif.

\section{Pengujian asumsi klasik}

\section{Uji ormalitas}

Pengujian normalitas data penelitian adalah untuk menguji apakah dalam model statistik variabel-variabel penelitian berdistribusi normal atau tidak normal. Model regresi yang tinggi adalah memiliki distribusi normal atau mendekati normal. Untuk menguji apakah distribusi normal atau tidak, salah satunya dengan menggunakan analisis grafik seperti pada gambar berikut : 


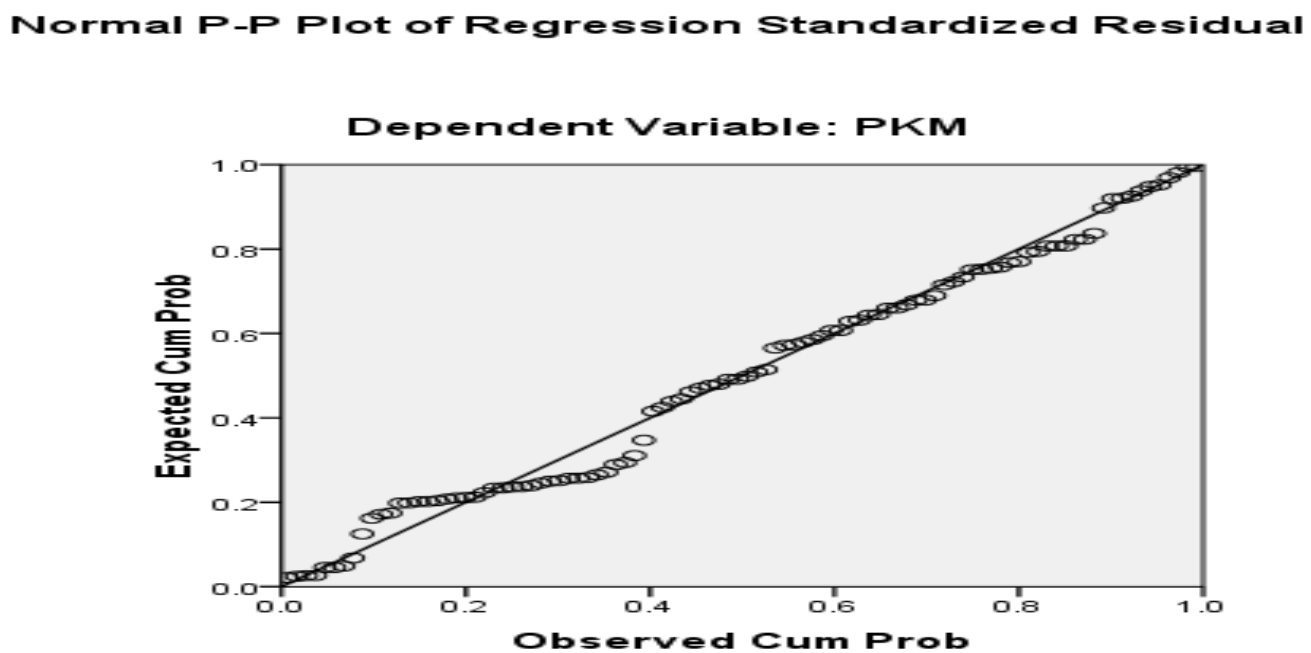

Sumber : Data diolah, 2020

Gambar 1. Grafik histogram uji normalitas

Gambar 1 mempertegas bahwa model regresi yang diperoleh berdistribusi normal, dimana sebaran data berada disekitar garis diagonal. Berdasarkan pada grafik histogram normal probabiliti, menunjukkan bahwa model regresi tersebut layak dipakai dalam penelitian karena memenuhi asumsi normalitas.

\section{Uji multikolinieritas}

Berdasarkan cirri-ciri yang diperlihatkan model analisis regresi berganda ternyata hanya model ke tiga yang menghasilkan model yang shahih, karena seluruh variabel bebas yang diuji menghasilkan pengaruh yang signifikan. Ini mengindikasikan model ke tiga terbebas dari perangkap multikolinearitas. Jika terdapat multikolinieritas makakoefisien regresi menjadi tak tentu, tingkat kesalahannya menjadi sangat besar dan biasanya ditandai dengan koefisien determinasi yang sangat besar tetapi pada pengujian parsial koefisien regresi, tidak ada ataupun kalau ada sangat sedikit sekali koefisien regresi yang signifikan. Pada penelitian ini digunakan nilai variance inflantion factors (VIF) sebagai ada tidaknya multikolinieritas diantara variabel bebas.

Tabel 3.Hasil pengujian asumsi multikolinieritas

\begin{tabular}{llcc}
\hline \multirow{2}{*}{ Model } & \multicolumn{2}{c}{ Collinearity Statistics } \\
\cline { 3 - 4 } & (Constant) & Tolerance & VIF \\
\hline Pddk & & \\
TK & .709 & 1.409 \\
JK & .838 & 1.193 \\
BH & .743 & 1.345 \\
& .674 & 1.483 \\
\hline
\end{tabular}

Sumber : Data diolah, 2020

Berdasarkan nilai VIF yang diperoleh pada masing variabel seperti terlihat pada Tabel 3 menunjukkan adanya korelasi yang cukup tinggi atau kuat antara sesama 
variabel bebas, dimana nilai VIF dari seluruh variabel bebas lebih kecil dari 10 sehingga dapat disimpulkan tidak terdapat multikolinieritas diantara variabel bebas.

\section{Uji autokorelasi}

Autokorelasi didefinisikan sebagai korelasi/keterkaitan antara serangkaian observasi yang diurutkan menurut waktu dan ruang. Untuk mengetahui ada atau tidaknya gejala autokorelasi dalam perhitungan regresi atas penelitian ini maka digunakan Durbin-Watson Test sebesar 1,947.Dengan menggunakan tabel statistik d dan derajat kepercayaan 95\% $(\alpha=0,05)$ jumlah observasi 98 serta jumlah variabel bebas 4 maka diperoleh. Hasil yang diperoleh adalah nilai DW observasi terletak pada daerah penerimaan (4-d)> dU atau dengan kata lain model regresi ke III tidak terdapat autokorelasi negatif dalam penelitian ini.

\section{Uji heteroskedastisitas}

Mendeteksi heteroskedastisitas dapat dilakukan dengan gambar grafik nilai-nilai residu, uji Breusch-Godfrey dan Uji Park. Penelitian ini menggunakan uji BreuschGodfrey.

\section{Scatterplot}

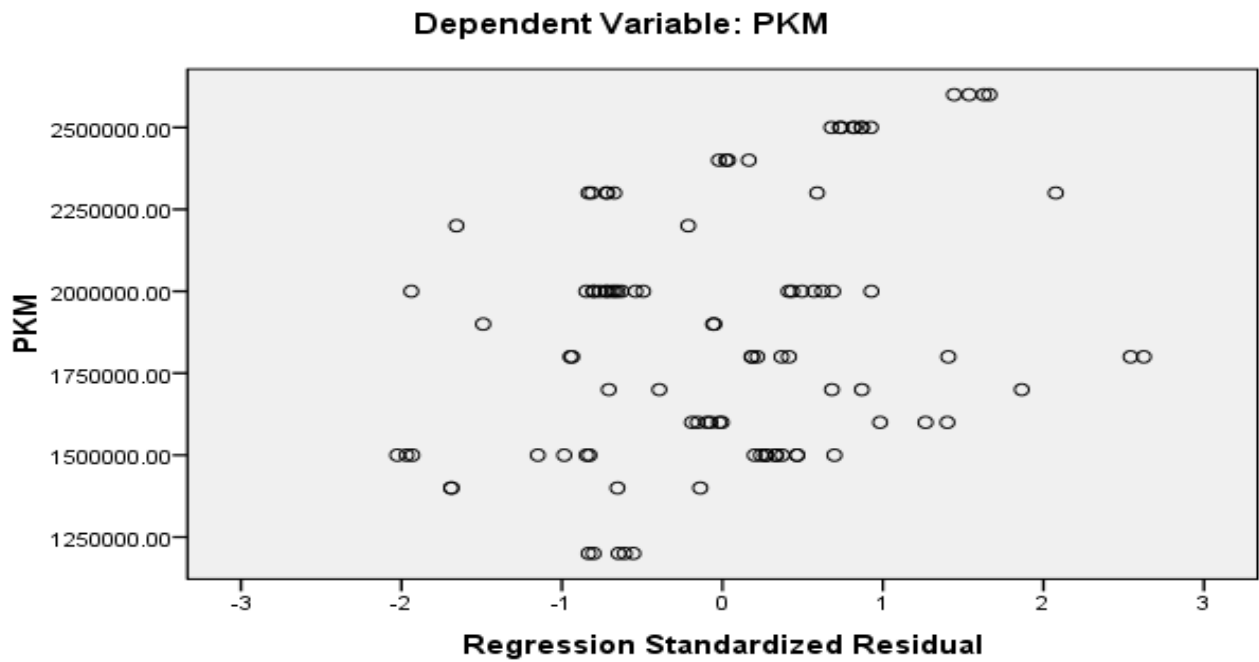

Sumber : Data diolah, 2020

Gambar 2.Uji heteroskedastisitas

Dengan melihat Gambar 2 diketahui bahwa tidak ada pola yang jelas serta titiktitik menyebar diatas dan dibawah 0 dan Sumbu Y. Maka dapat disimpukan tidak terjadi heteroskedastisitas pada model.Sehingga model yang dapat ditaksir dalam penelitian ini adalah tidak terdapat perangkap asumsi klasik

\section{Pengujian hipotesis}

\section{Pengujian hipotesis secara simultan (Uji F)}

Uji $F$ dilakukan untuk mengetahui pengaruh variabel independen secara simultan terhadap variabel.Untuk melakukan uji $\mathrm{F}$ dapat dilihat pada hasilanova dibawah ini: 
Tabel 4.Hasil uji F

\begin{tabular}{llrrrrr}
\hline Model & & Sum of Squares & df & Mean Square & \multicolumn{1}{c}{ F } & \multicolumn{1}{c}{ Sig. } \\
\hline 1 & Regression & $1.311 \mathrm{E} 13$ & 4 & $3.278 \mathrm{E} 12$ & 207.893 & $.000^{\mathrm{a}}$ \\
& Residual & $1.466 \mathrm{E} 12$ & 93 & $1.577 \mathrm{E} 10$ & & \\
& Total & $1.458 \mathrm{E} 13$ & 97 & & & \\
\hline
\end{tabular}

Sumber : Data diolah, 2020

Berdasarkan tabel 4diperoleh nilai sig probabilita sebesar $0,000<0,05$ artinya Ho ditolak dan Ha diterima danini berarti variabel tingkat pendidikan, jumlah tanggungan keluarga, jam kerja dan biaya hidup secara bersama-sama berpengaruh signifikan terhadap variabel pendapatan kepala rumah tangga miskin di Kota Jambi.

\section{Pengujian hipotesis secara parsial (Uji t)}

Uji $\mathrm{t}$ dilakukan untuk mengetahui apakah secara individu (parsial) variabelindependent mempengaruhi variabel dependent secara signifikan atau tidak. Jika tingkat signifikansinya dibawah 5\% maka secara parsial variabel independen jam kerja dan biaya hidupberpengaruh signifikan terhadap pendapatan rumah tangga miskin. Untuk mengetahui variabel apa saja yang berpengaruh signifikan secara parsial terhadap pendapatan rumah tangga miskin dapat dilihat sebagai berikut :

\section{Variabel tingkat pendidikan}

Berdasarkan tabel 4 dapat dilihat bahwa nilai probabilita tingkat pendidikan yaitu $0,000<0,05$ artinya Ho ditolak dan Ha diterima, jadi kesimpulannya yaitu variabel tingkat pendidikan berpengaruh signifikan terhadap pendapatan rumah tangga miskin di Kota Jambi. Dengan demikian hipotesis yang menyatakan variabel tingkat pendidikan berpengaruh signifikan terhadap pendapatan kepala rumah tangga miskin di Kota Jambi adalah benar dan terbukti.

\section{Variabel jam kerja}

Berdasarkan tabel 4 dapat dilihat bahwa nilai probabilita tanggungan keluarga yaitu $0,013<0,05$ artinya Ho ditolak dan Ha diterima, jadi kesimpulannya yaitu variabel jumlah tanggungan keluarga berpengaruh signifikan terhadap pendapatan rumah tangga miskin di Kota Jambi. Dengan demikian hipotesis yang menyatakan variabel jumlah tenaga kerja berpengaruh signifikan terhadap pendapatan kepala rumah tangga miskin di Kota Jambi adalah benar dan terbukti.

\section{Variabel jam kerja}

Berdasarkan tabel4 dapat dilihat bahwa nilai probabilita jam kerja yaitu $0,003<$ 0,05 artinya Ho ditolak dan Ha diterima, jadi kesimpulannya yaitu variabel jam kerja berpengaruh signifikan terhadap pendapatan rumah tangga miskin di Kota Jambi. Dengan demikian hipotesis yang menyatakan variabeljam kerja berpengaruh signifikan terhadap pendapatan kepala rumah tangga miskin di Kota Jambi adalah benar dan terbukti.

\section{Variabel biaya hidup}

Berdasarkan tabel 4 dapat dilihat bahwa nilai probabilita biaya hidup yaitu $0,001<0,05$ artinya Ho ditolak dan Ha diterima, jadi kesimpulannya yaitu variabel 
biaya hidup berpengaruh signifikan terhadap pendapatan rumah tangga miskin di Kota Jambi. Dengan demikian hipotesis yang menyatakan variabelbiaya hidup berpengaruh signifikan terhadap pendapatan kepala rumah tangga miskin di Kota Jambi adalah benar dan terbukti.

\section{Koefisien determinasi $\left(\mathbf{R}^{2}\right)$}

Analisis koefisiensi determinasi $\left(\mathrm{R}^{2}\right)$ digunakan untuk melihat beberapa besar variasi naik turunnya variabel terikat mampu dijelaskan oleh variabel bebas. Semakin mendekati angka 1 maka semakin sempurna variabel bebas mampu menjelaskan perubahan variabel terikat sebagai akibat perubahan yang terjadi pada variabel bebas. Seperti yang ditunjukkan pada hasil berikutini :

Tabel 5.Hasil uji determinasi

\begin{tabular}{|c|c|c|c|c|c|}
\hline Model & $\mathbf{R}$ & R Square & $\begin{array}{c}\text { Adjusted R } \\
\text { Square }\end{array}$ & $\begin{array}{l}\text { Std. Error of the } \\
\text { Estimate }\end{array}$ & Durbin-Watson \\
\hline 1 & $.948^{\mathrm{a}}$ & .899 & .895 & $1.25573 \mathrm{E} 5$ & 1.947 \\
\hline
\end{tabular}

Sumber: Data diolah, 2020

Berdasarkan tabel 5 dapat kita lihat model summary diketahui nilai $\mathrm{R}^{2}$ sebesar 0,899 . Artinya sebesar 89,9 persen variasi pendapatan kepala rumah tangga miskin mampu dijelaskan oleh variabel bebas dalam model, sedangkan sisanya 10,1 persen dijelaskan oleh variabel lain diluar penelitian.

\section{Analisis ekonomi}

Berdasarkan hasil analisis penelitian tentang pengaruh pendidikan, jumlah tanggungan, jam kerja dan biaya hidup terhadap pendapatan kepala rumah tangga miskin di Kota Jambi, maka dapat dianalisis lebih dalam dengan menjelaskan interpretasi hasil, membandingkan hasil denganteori dan menganalisis terjadinya pengaruh atau tidak berpengaruh variabel bebas terhadap variabel terikat.

Seperti dijelaskan sebelumnya bahwa dari ke empat variabel bebas yang digunakan dalam penelitian ini, yaitu tingkat pendidikan, jumlah tanggungan keluarga, jam kerja dan biaya hidup terhadap pendapatan keluarga miskin ternyata yang mampu memenuhi persyaratan analisis hanya dua variabel yaitu jam kerja dan biaya hidup. Akan tetapi peneliti mencoba untuk melakukan telaah mengapa variabel pendidikan dan jumlah tanggungan keluarga tidak memenuhi kriteria kesahihan yang dikembangkan oleh peneliti.

Lestari (2010) dalam penelitiannya yang yang menganalisis faktor-faktor yang berpengaruh terhadap pendapatan kepala rumah tangga miskin pada sektor informal di Desa Blahkiuh. Hasil penelitian menunjukkan bahwa umur, jumlah tanggungan, jam kerja dan pendidikan berpengaruh signifikan secara simultan terhadap pendapatan dan berpengaruh positif dan signifikan secara parsial. Variabel jam kerja merupakan faktor yang lebih dominan mempengaruhi pendapatan kepala rumah tangga miskin yang bekerja di sector informal di Desa Blahkiuh.

Siswanto (2013) dalam penelitiannya yang dalam penelitiannya faktor-faktor yang mempengaruhi pendapatan sopir angkutan pedesaan terminal Arjasa Kabupaten Jember. Hasil dari penelitian menunjukkan bahwa curahan jam kerja, lama pemakaian kendaraan dan pengalaman mempunyai pengaruh signifikan terhadap pendapatan sopir angkutan pedesaan, secara parsial variabel curahan jam kerja mempunyai pengaruh yang positif dan signifikan.

Russicaria dkk (2014) dalam penelitiannya yang menganalisis analisis faktor faktor yang mempengaruhi pendapatan kepala rumah tangga miskin pada sektor 
informal di Kecamatan Abiansemal Kabupaten Badung. Hasil penelitian menunjukkan bahwa umur kepala rumah tangga berpengaruh positif namun tidak singifikan terhadap pendapatan kepala rumah tangga. Tiga variabel lainnya yaitu tingkat pendidikan, jam kerja, dan jumlah tanggungan keluarga berpengaruh positif dan signifikan terhadap pendapatan kepala rumah tangga miskin pada sektor informal di Kecamatan Abiansemal Kabupaten Badung.

Tuyen (2015) dalam jurnal internasionalnya yang berjudul "Socio-Economic Determinants of Household Income among Ethnic Minorities in the North-West Mountains, Vietnam". Penelitian ini bertujuan untuk mengetahui faktor-faktor yang berpengaruh terhadap pendapatan rumah tanggadi Pegunungan Barat Laut - wilayah termiskin di Vietnam. Alat analisis yang digunakan yaitu regresi linier berganda. Hasil penelitian ini menunjukkan bahwapendidikan, pekerjaan di luar pertaniandan aset tetap berpengaruh terhadap pendapatan rumah tangga.

Nurfahmi (2017) dalam penelitiannya yang berjudul analisis faktor-faktor yang mempengaruhi pendapatan pengemudi Becak Wisata (studi kasus paguyuban pengemudi becak wisata di kota jogja. Hasil penelitian menunjukkan responden yang paling banyak berumur 30-50 tahun dengan penghasilan setiap bulan kurang dari 1,5722 juta yaitu 40 orang $(53,3 \%)$, bekerja maksimal 8 jam sehari dengan penghasilan setiap bulan kurang dari 1,5722 juta yaitu 42 orang (56\%) dan mempunyai tanggungan keluarga lebih dari 3 orang dengan penghasilan setiap bulan kurang dari 1,5722 juta yaitu 36 orang (48\%). Hasil uji product moment dapat disimpulkan bahwa ada pengaruh umur terhadap pendapatan pengemudi becak wisata, ada pengaruh jam kerja terhadap pendapatan pengemudi becak wisata dan tidak ada pengaruh jumlah tanggungan terhadap pendapatan pengemudi becak wisata.

Febriadi, dkk (2018) dalam jurnal penelitiannya yang berjudul pengaruh tingkat pendidikan, curahan jam kerja dan jumlah tanggungan terhadap pendapatan rumah tangga miskin pada masyarakat Nagari Sungai Lansek Kecamatan Kamang Baru Kabupaten Sijunjung.. Hasil penelitian menunjukkan bahwa variabel yang berpengaruh signifikan terhadap pendapatan adalah variabel tingkat pendidikan, curahan jam kerja dan jumlah tanggungan.

\section{KESIMPULAN DAN SARAN}

\section{Kesimpulan}

Berdasarkan karakteristik sosial dan ekonomi pada keluarga miskin usia produktif bahwa rata-rata kepala rumah tangga miskin di Kota Jambi memilki lama pendidikan formal selama 9 tahun, berusia 46 tahundan memiliki 4 orang tanggungan. Kemudian kepala rumah tangga miskin di Kota Jambi bekerja selama 10 jam perhari dengan biaya hidup yang harus dipenuhi oleh kepala rumah tangga miskin sebesar Rp. 2.061.000 perbulan namun pendapatan yang diterima perbulan hanya Rp. 1.800.000. Jumlah rumah tangga miskin tertinggi berada di Kecamatan Jambi Timur dengan jumlah sebanyak 3.061 rumah tangga miskin dari total 15.788 rumah tangga dengan ratio 20 : 100. Ratio rumah tangga miskin terhadap total rumah tangga tertinggi ada di Kecamatan Danau Teluk dengan perbandingan 30:100. Jumlah rumah tangga miskin terendah di Kecamatan Pelayangan dengan jumlah sebanyak 376 rumah tangga miskin dari total 3.396 rumah tangga, dengan rasio sebesar 11:100. Rasio rumah tangga miskin terhadap total rumah tangga terendah berada di Kecamatan Alam Barajo dengan perbandingan $4: 100$ Berdasarkan hasil regresi linier berganda dapat disimpulkan bahwa variabel jam kerja dan biaya hidup secara bersama-sama berpengaruh signifikan terhadap pendapatan kepala rumah tangga miskin di Kota Jambi, laluvariabel jam kerja dan biaya hidupsecara parsial berpengaruh signifikan terhadap pendapatan kepala 
rumah tangga miskin.Besarnya pengaruh jam kerja dan biaya hidup yaitusebesar 28,9 persen terhadap variabel pendapatan kepala rumah tangga miskin.

\section{Saran}

Seharusnya kepala rumah tangga miskin lebih giat lagi dalam meningkatkan pendapatan karena pendapatannya belum mencukupi biaya hidupkeluarganya yang memiliki jumlah tanggungan sebanyak 4 orang. Untuk kepala rumah tangga yang sudah berumur lebih dari 50 tahun agar mulai meninggalkan pekerjaan seperti buruh harian lepas dan pekerjaan yang melibatkan fisik lainnyakarena pekerjaan ini sangat membutuhkan tenaga yang kuat sementara diumur 50 tahun ketas produktivitas seseorang akan menurun. Untuk kepala rumah tangga miskin yang memiliki telah menghabiskan waktu pendidikan formal selama 12 tahun atau kurang dari 12 tahun agar dapat mengikuti pelatihan-pelatihan dari Balai Latihan Kerja untuk mendapatkan ilmu dan skill untuk bekerja agar mendapatkan pekerjaan dengan pendapatan yang lebih baik.Seharusnya kepala rumah tangga miskin di Kota Jambi meminta kepada anggota keluarga misalnya anak yang sudah cukup umur untuk bekerja agar dapat bekerja sehingga dapat meringankan biaya hidup kepala rumah tangga dalam memenuhi kebutuhan hidup keluarganya.Kemudian kepala rumah tangga miskin harusnya dapat menambah jam kerja dan mencari pekerjaan lain atau pekerjaan sampingan untuk menambah pendapatan. Kemudian kepala rumah tangga miskin dan anggota keluarga lainnya juga harus berupaya meminimalisir pengeluaran, hal ini dapat mengurangi biaya hidup yang menjadi beban kepala rumah tangga.

\section{DAFTARPUSTAKA}

Asmie. (2008). Lama usaha. Erlangga: Jakarta.

Ghozali, Imam. (2012). Aplikasi analisis multivariate dengan program IBM SPSS. Universitas Diponegoro: Yogyakarta.

Gani, Irwan dan Amalia, Siti. (2015). Alat analisis data: aplikasi statistik untuk penelitian bidang ekonomi dan sosial. PT. Andi Offset: Yogyakarta.

Gudjarati, Damodar. (2005). Ekonometrika. Rajawali Press: Jakarta.

Lestari, Wiwiek Dwi. (2010). Analisis faktor-faktor yang berpengaruh terhadap pendapatan kepala rumah tangga miskin pada sektor informal di Desa Blahkiuh. Skripsi Fakultas Ekonomi Universitas Udayana: Denpasar.

Manurung. J (2008). Ekonomi sumberdaya manusia. Ghalia Indonesia: Jakarta

Raharja, Pratama dan Mandala Manurung. (2008). Teori ekonomi makro. Fakultas Ekonomi Universitas Indonesia: Jakarta.

Russicaria, I. G. D., \& Djayastra, W. I. K. (2014). Analisis faktor - faktor yang mempengaruhi pendapatan kepala rumah tangga miskin pada sektor informal di Kecamatan Abiansemal Kabupaten Bandung. E-Jurnal Ekonomi Pembangunan Universitas Udayana.. 3(4), 134-144.

Simanjuntak. (2001). Pengantar ekonomi sumber daya manusia Edisi 2001. FEUI: Jakarta.

Sutrisno, Hadi, (2006). Pengantar statistik. Penerbit Rineka Cipta: Jakarta

Siswanto, Dwi. (2013). Faktor-faktor yang mempengaruhi pendapatan sopir angkutan pedesaan terminal arjasa Kabupaten Jember. Skripsi. Ilmu Ekonomi Dan Studi Pembangunan Universitas Jember: Jawa Timur

Makridakis. (1994). Metode peramalan. Rajawali Press: Jakarta

Tuyen, Tran Quang. (2015). Socio-economic determinants of household income among ethnic minorities in the north-west mountains Vietnam. Croatian Economic Survey. 17(1), 135-159. 